\title{
A SELFIE DO MACACO - AUTORIA E FOTOGRAFIA NA CONTEMPORANEIDADE
}

\section{Rui Carlos Sloboda Bittencourt ${ }^{1}$ Walter Guandalini Junior ${ }^{2}$}

\author{
When acclaiming our modern heroes, let's not forget The News Reel \\ Cameraman... the daredevil who defies death to give us pictures of the \\ world's happenings. [ ... $]$ \\ And there are other types of photographers. ${ }^{3}$ \\ The Cameraman, 1928.
}

\section{Resumo}

O artigo tem por objeto a disputa pela autoria da fotografia intitulada selfie do macaco. Embora o registro tenha sido realizado pelo macaco naruto, o fotógrafo profissional david slater reivindica a autoria da foto, que foi incluída no banco de mídias digitais wikimedia commons e passou a circular livremente, o que deu início a uma disputa judicial por sua autoria. Deixando de lado questões dogmáticas como a decisão sobre a atribuição da autoria, o presente artigo pretende analisar o caso de uma perspectiva filosófico-crítica: levando em consideração o debate estético sobre a natureza da produção fotográfica e o sentido da arte na era da reprodutibilidade técnica, a selfie do macaco é reinserida no contexto da indústria cultural e da ascensão da selfie como gênero fotográfico. Seguindo a recomendação metodológica de deleuze e guattari, o texto se organiza em platôs, de forma rizomática, com o objetivo de estabelecer agenciamentos capazes de produzir uma cartografia das disputas em torno do direito autoral na contemporaneidade. Assim, o caso é comparado com situações similares de modo a expandir o campo de investigação, o que permite a conclusão de que não é peculiar, mas sintomático da crise da autoria na contemporaneidade.

Palavras-chave: direitos autorais; fotografia; estética fotográfica; autoria; indústria cultural.

\footnotetext{
${ }^{1}$ Mestrado em Direitos Fundamentais e Democracia pelo Centro Universitário Autônomo do Brasil (Unibrasil). Professor de Direito Civil e Teoria da Argumentação no Centro Universitário Autônomo do Brasil. Membro do Núcleo de Pesquisa em Direito Civil e Constituição e da Associação Portuguesa de Direito Intelectual. E-mail: bittencourt@jurua.com.br.

${ }^{2}$ Doutorado em Direito do Estado pela Universidade Federal do Paraná (2012). Realizou programa de Doutorado com Estágio no Exterior (PDEE - Doutorado-sanduíche) pelo Centro di Studi per la Storia del Pensiero Giuridico Moderno, na Università di Firenze (2010). Professor adjunto da Faculdade de Direito da Universidade Federal do Paraná. E-mail: prof.walter.g@gmail.com.

3 "Ao aclamarmos nossos heróis modernos, não esqueçamos do cinegrafista de cinejornal... O bravo que desafia a morte para nos dar imagens dos acontecimentos do mundo. [...]

E há outros tipos de fotógrafos" (O Homem das Novidades, 1928 - tradução livre).
} 


\section{METATEXTO: RIZOMA}

O protocolo acadêmico exige um aviso. Um aviso que não é uma introdução, porque não pretende esclarecer de onde partimos e aonde pretendemos chegar, metodologia e resultados, pois não há começo ou fim quando a escrita se espalha em rizoma, estabelecendo conexões múltiplas entre pensamentos independentes. "A árvore impõe o verbo ser, o rizoma tem como tecido a conjunção e... e... e...", avisam Deleuze e Guattari (2000:37), para observar que ele se encontra sempre no meio, entre as coisas, realizando um movimento transversal que sacode e desenraiza o próprio ser.

Quando um texto é feito por capítulos, ele possui pontos culminantes de conclusão, que estabilizam a reflexão subjetiva de seu autor na verdade ontológica do ser. Este é o oposto do que se pretende com este artigo, que, inspirando-se nas recomendações de Deleuze e Guattari (2000:33), organiza-se em platôs independentes, que podem ser lidos sem qualquer sistema: para que as ideias se comuniquem livremente umas com as outras através de microfendas, estabelecendo uma multiplicidade conectável com outras hastes subterrâneas superficiais, de maneira a formar e estender o rizoma. Desse modo, apenas como metáfora se pode dizer que este texto siga uma "metodologia". Não por falta de atenção ou respeito ao rigor científico, mas porque não intenta construir uma ontologia, e sim uma cartografia, oposta a qualquer modelo genético ou estrutural e capaz de contribuir estrategicamente para o desbloqueio do pensamento nômade, ressituando os impasses no mapa para reabri-los sobre linhas de fuga possíveis. Deleuze e Guattari esclarecem:

O mapa é aberto, é conectável em todas as suas dimensões, desmontável, reversível, suscetível de receber modificações constantemente. Ele pode ser rasgado, revertido, adaptarse à montagens de qualquer natureza, ser preparado por um indivíduo, um grupo, uma formação social. Pode-se desenhá-lo numa parede, concebê-lo como obra de arte, construílo como uma ação política ou como uma meditação. Uma das características mais importantes do rizoma talvez seja a de ter sempre múltiplas entradas (DeLEUZE E GUATTARI, 2000:22).

Trata-se, em suma de criar uma estabilização intensiva e uma multiplicidade conceitual, por meio da qual em cada platô se construa um mapa particular que, espera-se, contribua para o nossa localização estratégica nos embates sobre a propriedade intelectual na contemporaneidade. Mas nenhum mapa tem pretensão de fixidez (e os modernos GPS insistem em nos lembrar disso a cada nova contramão): ele é apenas útil enquanto existirem os pontos de referência que indica, e precisa se adaptar a cada nova transformação topológica do terreno que pretende mapear.

Nesse sentido, se o objeto deste artigo poderia ser tradicionalmente definido como "a selfie do macaco", é preciso que se compreenda que este é somente um dos múltiplos agenciamentos que podem se realizar a partir dele. A fotografia que intitula o texto é apenas um (importante) ponto de referência no interior de um campo de problemas muito mais abrangente, para o qual se apresentam argumentos que talvez possibilitem a construção de trincheiras em posições mais vantajosas, mas que não passam, eles próprios, também de pontos de referência. E a vol. 08, nº. 04, Número Especial. 2015.pp. 2233-2260 
um ponto de referência não se pergunta em quê consiste a sua essência: usa-se-o, se serve; ignora-se-o, se não. Mas, se está ali, um cartógrafo prudente não pode deixar de indicá-lo.

É também por esse motivo que o texto está recheado de exemplos: porque não deseja ser fixado pela âncora da selfie do macaco, enraizar-se para reduzir ao Uno a multiplicidade do real; deseja flutuar, ser rizoma, transformando o ponto em linha de fuga, e os conceitos em circunstâncias e agenciamentos. Desse jeito, não começa nem conclui: cria uma máquina de guerra que para os que desejem participar do combate.

\section{"E HÁ OUTROS TIPOS DE FOTÓGRAFOS"}

O Homem das Novidades (The Cameraman), filme mudo dirigido por Edward Sedgwick e Buster Keaton em 1928, inicia com a aclamação de um herói que no início do século XX era considerado "moderno", mas que os breves 100 anos de história da comunicação de massa já conseguiram relegar ao museu da indústria cultural: o cinegrafista de cinejornal. Criado em 1908, o cinejornal (ou Newsreel) era um documentário em curtametragem exibido como noticiário nas salas de cinema antes das atrações principais. Tornou-se especialmente popular durante a 2a Guerra Mundial, quando passou a ser utilizado como propaganda de guerra pelos dois lados do confronto, até ser suplantado pelo telejornal no início dos anos 60 e desaparecer definitivamente nos anos $80^{4}$. Durante esse período o cinegrafista de cinejornal desempenhou um papel similar ao do atual repórter de guerra, colocando-se em situações de perigo e arriscando a própria vida para obter a notícia e informar o telespectador.

Mas o próprio filme, após homenagear a personificação jornalística do arquétipo transcendental do Autor heroico moderno (com uma sequência de registros de guerras e incêndios), subverte a homenagem, reconhecendo que também "há outros tipos de fotógrafos" - frase de duplo sentido que apenas vai se revelar completamente ao final do filme.

De início, o "outro tipo" é Buster: o desastrado fotógrafo interpretado por Buster Keaton que ao se apaixonar por Sally (Marceline Day), a bela secretária do cinejornal da MGM, decide tornar-se também cinegrafista para ficar mais próximo de sua amada. Buster é realmente "outro tipo de fotógrafo": não por faltar-lhe a coragem que caracteriza o autor moderno, mas por faltar-lhe a perícia técnica de que necessita para realizar o trabalho com qualidade, o que conduz a uma série de acidentes e situações de vaudeville que acabam arruinando as suas chances de obter o novo emprego e a namorada.

Mesmo assim o nosso herói não desiste: após receber a dica de que a empresa estaria interessada em imagens de uma festa popular que ocorreria no bairro de Chinatown, em Los Angeles, Buster se dirige para lá mas no caminho tromba com um tocador de realejo e aparentemente mata o seu macaco, sendo obrigado a

\footnotetext{
${ }^{4}$ O mais famoso exemplo brasileiro é o Canal 100, que de 1959 a 1986 produziu um cinejornal por semana, mas acabou se tornando popular pelas filmagens de partidas de futebol.
} 
comprá-lo. Na sequência se descobre que o macaquinho sobrevivera, e ele passa a acompanhar Buster na filmagem da festa. Durante a celebração tem início uma guerra de gangues, que Buster registra corajosamente apenas para descobrir, ao final do dia, que havia esquecido de inserir o filme na câmera.

Desapontado, desiste do emprego, mas não da arte: enquanto filmava uma corrida de lanchas percebe Sally em perigo, após ter sido derrubada de uma lancha em alto mar. Buster demonstra novamente todo o seu heroísmo, deixando a câmera e mergulhando no mar para salvá-la, apenas para ver novamente a sua dedicação menosprezada quando seu rival amoroso e profissional rouba-lhe o crédito pelo salvamento.

Mas há ainda "outro tipo de fotógrafo": ao final se descobre que durante o registro da guerra no bairro chinês o próprio macaquinho havia inserido o filme na câmera, tendo-o substituído após a filmagem; não bastasse, havia registrado também todo o salvamento de Sally por Buster, restituindo-lhe a autoria do ato de bravura. "That's the best camera work I've seen in years!"5, exclama o editor da MGM, assombrado. O cameraman finalmente conquista o emprego e a mocinha, em uma celebração simbólica da superação das limitações de uma sociedade mecanicista com a reconciliação das relações pessoais a despeito de quaisquer obstáculos (como interpreta a crítica de ANDRADE, 2010).

Mas quem é o cameraman?

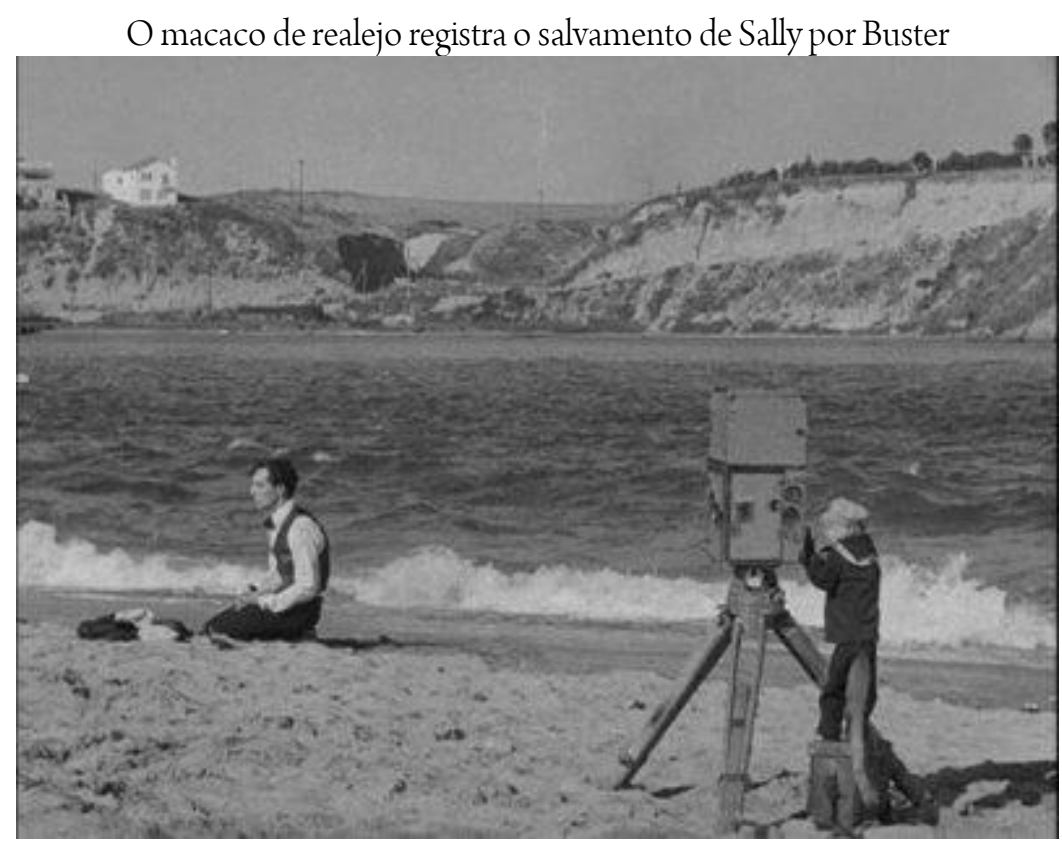

Fonte: The Cameraman, $1928^{6}$

\footnotetext{
5 "É o melhor trabalho de câmera que eu vejo em anos!" (tradução livre).

${ }^{6}$ Disponível em 24/10/2014 no sítio eletrônico <http://prettycleverfilms.com/files/2012/07/33805900.jpg>.
} vol. 08, no. 04, Número Especial. 2015.pp. 2233-2260 


\section{A SELFIE DO MACACO}

\section{A vida imita a arte}

Em 2011 o fotógrafo britânico David J. Slater, especializado em vida selvagem, decidiu embarcar em um tour fotográfico para uma área de floresta tropical ao norte da ilha de Celebes, na Indonésia. A região norte da ilha abriga sete espécies diferentes de macacos, e cada uma ocupa pequenas porções de território que se completam como um quebra-cabeças, o que interessou o fotógrafo: afirma ter sido atraído pelo objetivo nobre de compreender os motivos da pouca competição por comida e da rara disputa territorial entre as espécies, e assim talvez "aprender alguma coisa sobre a coexistência pacífica com outras culturas" (SLATER, 2014a - tradução livre $)^{7}$.

Durante a viagem Slater se interessou particularmente pela espécie Macaca Nigra, "uma espécie surpreendentemente fotogênica”; impressionaram-no sobretudo as suas características humanas: o penteado punk, a curiosidade e esperteza, mas também os "penetrantes e hipnóticos olhos vermelhos" (SLATER, 2014a tradução livre $)^{8}$. Em seu site oficial conta ter seguido um grupo deles por três dias, com a orientação de um guia local (cujo nome não chega a ser mencionado), retornando ao acampamento somente para dormir. Em sua narração é enfático ao descrever o difícil trabalho de seguir os macacos pela floresta úmida carregando $20 \mathrm{~kg}$ de caros equipamentos fotográficos. Por volta do meio-dia do segundo dia um grupo de aproximadamente 25 macacos parou para descansar, e ele tentou se aproximar para fotografá-los.

Nesta primeira aproximação um dos macacos tentou roubar a câmera de Slater, que foi rapidamente recuperada pelo guia. O fotógrafo voltou a preparar a câmera e os macacos novamente se interessaram por ela; mais uma vez precisava recorrer ao auxílio do guia para evitar que os animais fugissem com o equipamento. Enquanto o guia lutava com os macacos para recuperar a câmera, Slater escutou o som de avanço do filme fotográfico e teve um insight: "a cena estava preparada":

I decided to set up the camera on a beanbag on a log, self-timer all set. I was afraid they would run off of course, but they didn't. Rather, they grabbed my camera! Quick thinking had my guide rushing to save it - lesson learnt. Setting up the camera again, some of the cheekier monkeys had now got bored, and now even my guide had wandered off for a smoke. I was alone and had to encourage the monkeys back to me for my intended contact experience photo. Soon enough, I was jokingly asking for his help again as the monkeys looked increasingly cheeky as they touched the camera with that glint in their piercing red eyes. It

\footnotetext{
7 "Sulawesi has 7 different macaque species on the island., each occupying rather small ranges that interlock like a jigsaw. Why there is little direct competition for food or territorial disputes is a mistery, and perhaps we humans have something to learn from them about peaceful co-existence with other cultures" (SLATER, 2014a).

8 "An amazingly photogenic species of monkey confined to the volcanic dry tropical forest in the far north of Sulawesi. They are more amazing due to their very human-like characteristics, not least their "punk" hairdo, but they are also very inquisitive and clever. But their piercing red eyes seal fascination for me; mesmerizing yet unnerving when they make eye-contact with you - a memory of our ancient ancestors?" (SLATER, 2014a).
} 
was now that I heard some frames reeled off when my guide struggled to keep the camera from little monkey fingers - the scene was set (SLATER, 2014a)

Assim, decidiu montar a câmera sobre um tripé, configurando-a de modo a aumentar as chances de um close up de rosto: lente grande angular, foco automático, avanço de filme e flash automáticos. Afastou-se do equipamento e deixou que os macacos se aproximassem; eles brincaram com a câmera por aproximadamente trinta minutos, "até que, é claro, algumas fotografias foram inevitavelmente tiradas" (SLATER, 2014a) ${ }^{10}$. Dentre elas, a célebre fotografia do rosto do macaco Naruto sorrindo para a câmera, reproduzindo as características de uma selfie.

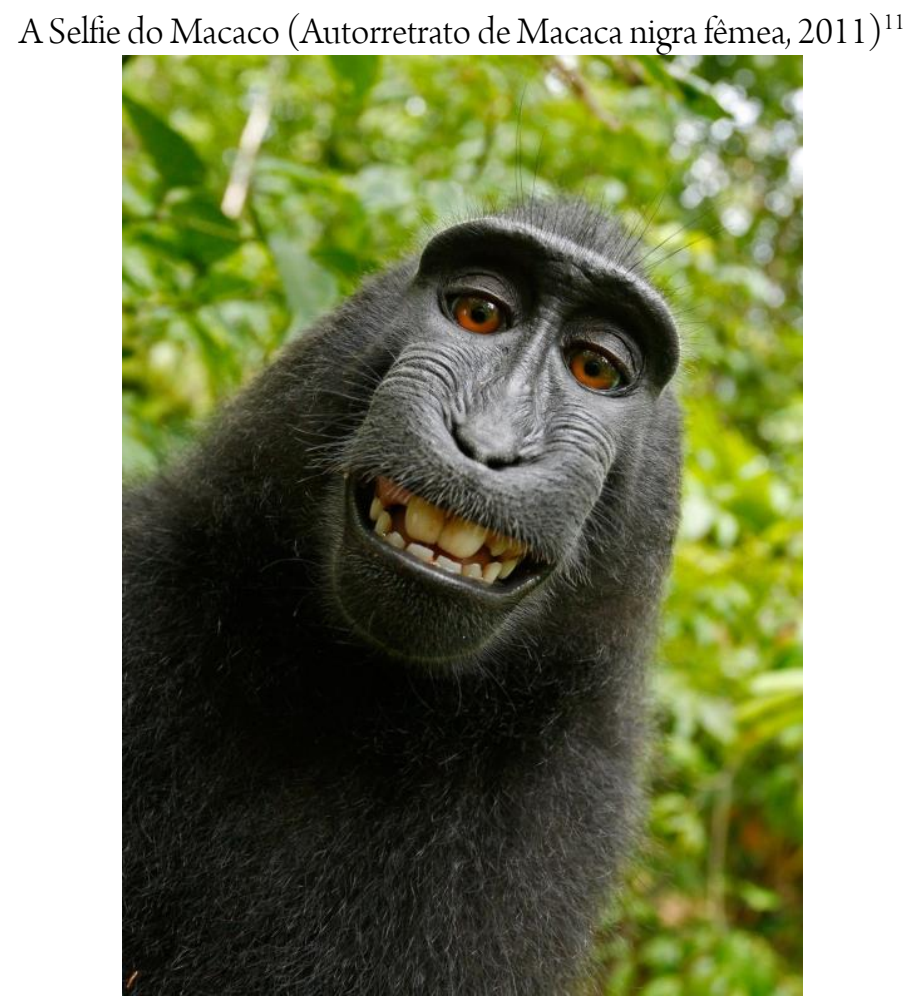

\footnotetext{
9 "Eu decidi preparar a câmera em uma almofada sobre um tronco, com o temporizador ligado. Estava com medo de que eles fugissem, é claro, mas eles não fugiram. Em vez disso, pegaram minha câmera! O pensamento rápido do meu guia fez com que ele corresse para salvá-la - lição aprendida. Enquanto eu preparava a câmera novamente, alguns dos macacos mais insolentes já estavam entediados, e até o meu guia tinha saído para fumar um cigarro. Eu estava sozinho e tinha que encorajar os macacos a voltarem para a minha experiência fotográfica. Em pouco tempo eu voltava a pedir a sua ajuda por brincadeira, pois os macacos pareciam cada vez mais audaciosos ao tocarem a câmera com aquele brilho nos seus penetrantes olhos vermelhos. Foi então que eu ouvi o filme sendo avançado enquanto o meu guia se esforçava para manter a câmera longe dos dedinhos dos macacos - a cena estava preparada (SLATER, 2014a - tradução livre).

10 "So I put my camera on a tripod with a very wide angle lens, settings configured such as predictive autofocus, motorwind, even a flashgun, to give me a chance of a facial close up if they were to approach again for a play. I duly moved away and bingo, they moved in, fingering the toy, pressing the buttons and fingering the lens. I was then to witness one of the funniest things ever as they grinned, grimaced and bared teeth at themselves in the reflection of the large glassy lens. Was this what they where afraid of earlier? Perhaps also the sight of the shutter planes moving within the lens also amused or scared them? They played with the camera until of course some images were inevitably taken! I had one hand on the tripod when this was going on, but I was being prodded and poked by would be groomers and a few playful juveniles who nibbled at my arms. Eventually the dominant male at times became over excited and eventually gave me a whack with his hand as he bounced off my back. I new then that I had to leave before I possibly got him too upset. The whole experiance lasted about 30 minutes" (SLATER, 2014a).
}

${ }^{11}$ Disponível no sítio eletrônico <http://upload.wikimedia.org/wikipedia/commons/5/52/Macaca_nigra_self-portrait.jpg> em $24 / 10 / 2014$. 


\section{Inevitável é a pergunta: "foram inevitavelmente tiradas" por quem?}

A versão original da história, tal como divulgada pela imprensa em 2011, dava uma resposta um pouco mais incisiva a esta pergunta: na entrevista concedida ao jornal britânico The Telegraph, que tornou a história famosa e particularmente interessante, Slater dizia que "o macaco deve ter tirado centenas de fotos até eu ter minha câmera de volta" (TELEGRAPH, 2011 - sem grifos no original) ${ }^{12}$. A entrevista era ilustrada por algumas das fotografias "feitas pelos macacos", que acabaram sendo replicadas no mundo inteiro por outros jornais, websites e nas redes sociais.

Logo após a publicação alguém teve a ideia de enviar as fotos mais famosas da série para a Wikimedia Commons, banco de mídias digitais com conteúdo livre mantido pela Wikimedia Foundation. A fundação se define como "uma organização beneficente, sem fins lucrativos, dedicada a incentivar a produção, desenvolvimento e distribuição de conteúdo livre e multilíngue e a disponibilizar ao público, integralmente, esses projetos baseados em wiki de forma totalmente gratuita"13. Desse modo, segundo os princípios da organização, uma vez inseridas no banco Wikimedia Commons as fotografias poderiam ser livremente copiadas por qualquer interessado, sem necessidade de pagamento. Slater considerou a publicação uma violação de seus direitos de autor e deu início a uma disputa judicial pela autoria das fotografias.

A defesa da Wikimedia Foundation fornece outra resposta à pergunta inevitável: para a fundação as fotos foram "inevitavelmente tiradas" por ninguém, já que o macaco, não sendo pessoa, não pode ser titular de propriedade intelectual. Argumenta que se não foi Slater quem disparou a câmera ele não possui os direitos sobre a imagem, que pode ser livremente utilizada por qualquer interessado.

A controvérsia se tornou ainda mais complexa em setembro de 2015: a PETA, ONG dedicada ao tratamento ético de animais, decidiu representar Naruto, o próprio macaco fotografado, em ação judicial destinada a reivindicar para ele a autoria da fotografia, proposta perante a Corte Federal de São Francisco, nos Estados Unidos. Segundo Naruto ${ }^{14}$, o conjunto de fotografias denominadas Selfies do Macaco é resultado de suas ações, realizadas voluntariamente e sem o auxilio de Slater. Argumenta que os indivíduos de sua espécie são altamente inteligentes, capazes de raciocínio avançado, de utilizar as mãos em tarefas complexas e de aprendizado por experiência. Esclarece que a sua comunidade já havia tido contatos com turistas e fotógrafos profissionais, durante os quais teria observado o uso de câmeras e aprendido a operá-las. Desse modo, considerando que a lei de copyright americana é suficientemente ampla para permitir que a sua proteção se estenda a qualquer trabalho

\footnotetext{
12 "He must have taken hundreds of pictures by the time I got my camera back, but not very many were in focus. He obviously hadn't worked that out yet” (TELEGRAPH, 2011).

${ }^{13}$ Segundo o sítio oficial da fundação, disponível em 16 de outubro de 2014 no endereço <http:/ / wikimediafoundation.org>.

${ }^{14}$ Evidentemente, representado pela ONG. A petição inicial da ação está disponível em 30 de setembro de 2015 no sítio eletrônico $<$ http://www.mediapeta.com/peta/PDF/Complaint.pdf>.
} 
original ${ }^{15}$, inclusive de animais, reclama a autoria das fotografias e pede que se conceda à PETA o direito de administrá-las em seu nome, com a condição de que todos os valores decorrentes de seu uso comercial sejam empregados exclusivamente em seu benefício, de sua família e comunidade, e na preservação de seu habitat.

\section{QUEM É O AUTOR DESSAS FOTOGRAFIAS?}

Iesus itaque sciens omnia quae ventura erant super eum processit et dicit eis quem quaeritis (Ioannes, 18:4) $)^{16}$.

\section{As Crianças de Aubervilliers}

Nos anos 80 o hospital psiquiátrico entrou no foco do debate político. A crítica foucaultiana à psiquiatria já havia extrapolado os muros da academia e o movimento antimanicomial se tornava cada vez mais forte, ao mesmo tempo em que a arte demonstrava o seu interesse pelo tema em uma profusão de produções cinematográficas, literárias, fotográficas que abordavam a vida no hospício. É nesse contexto que Marc Pataut decide realizar a sua fotorreportagem sobre o manicômio.

Em meio a tantas obras, Pataut decide dar um passo além e aprofundar o seu contato com a realidade, vivendo e trabalhando em um hospital psiquiátrico. Foi assim que entrou em contato com o hospital-dia destinado a crianças de Aubervilliers, no subúrbio de Paris. A equipe do serviço, que se ocupava de crianças classificadas como psicóticas, recrutava pessoas alheias ao mundo psiquiátrico para participarem do tratamento a partir de sua própria formação e experiência. Como fotógrafo profissional, Pataut é convidado a "fazer fotografia" com as crianças, e propõe um trabalho em três etapas (como explica SOULAGES, 2010:164): primeiro, reelabora as condições da encomenda e entra em contato com as crianças; depois, fotografa as crianças durante um mês; por fim, entrega as câmeras às crianças para que fotografem como desejarem (o objetivo principal da atividade).

O procedimento é simples: a cada vez, Pataut insere o filme na máquina e bate a primeira foto, um retrato de cada criança a receber uma câmera. Com isso, não só estabelece para a criança uma primeira forma de relação entre autor e objeto fotográfico, mas também "assina" as fotografias de cada criança com um retrato de seu autor

\footnotetext{
${ }^{15}$ Copyright Act, 17 U.S.C. $\$ 102:$

$\$ 102$. Subject matter of copyright: In general

1. Copyright protection subsists, in accordance with this title, in original works of authorship fixed in any tangible medium of expression, now known or later developed, from which they can be perceived, reproduced, or otherwise communicated, either directly or with the aid of a machine or device.
}

Em tradução livre:

$\$ 102$. Matéria sujeita a copyright: Em geral

1. A proteção do copyright consiste, de acordo com este título, em trabalhos originais de autoria ficados em qualquer meio de expressão tangível, conhecido atualmente ou posteriormente desenvolvido, a partir do qual possa ser percebido, reproduzido ou de qualquer modo comunicado, diretamente ou com auxílio de uma máquina ou dispositivo.

${ }^{16}$ Sabendo, pois, Jesus todas as coisas que sobre ele haviam de vir, adiantou-se, e disse-lhes: A quem buscais? (João, 18:4). vol. 08, no. 04, Número Especial. 2015.pp. 2233-2260 
no início de cada filme - como recorda Soulages (2010:166), é esse o modo usual de assinatura dos trabalhos de repórteres fotográficos: um autorretrato no início do filme. François Soulages descreve as reações das crianças ao receberem as câmeras:

A primeira sessão dá lugar a comportamentos muito variados: $\mathrm{A}$ abre várias vezes a máquina e diz: "Não tem pilha" e então a joga no chão, decepcionado; B não tira foto, devolve a máquina e pede para ser fotografado; $\mathrm{C}$ usa a máquina ao contrário, depois a abandona; $\mathrm{D}$ coloca, corretamente, a máquina diante do olho, mas não tira foto e, depois de um certo tempo, pergunta quantas fotos lhe restam; Pataut lhe diz quantas; ele tira uma foto e pergunta novamente quantas the restam... e assim sucessivamente até o fim do filme; E faz todas as fotos em trinta segundos, confundindo o mecanismo de disparo com o de fazer o filme avançar; F compreendeu bem o princípio da tomada de imagem e fotografa corretamente, mesmo quando a máquina está sem filme; $\mathrm{G}$ não tira fotos, e $\mathrm{H}$ as tira em seu lugar (SOULAGES, 2010:166).

De início, o objetivo das crianças não é obter uma fotografia, mas fazer a máquina funcionar; a atividade fotográfica se esgota em si mesma, na apropriação do instrumento e em sua utilização. Assim, fotografam o céu, a terra, as paredes, como se aprende o manejo de uma máquina e se estabelece uma relação de controle com ela e os objetos submetidos ao seu poder.

Muitos fotografam o seu próprio corpo. Como se a máquina não passasse de uma extensão do corpo, e a fotografia o reconhecimento de si mesmo; ou como se o corpo fosse externo ao self, e a máquina o instrumento de sua reapropriação. Rapidamente passam a fotografar também o outro, tornando a câmera instrumento de comunicação com o mundo exterior - carinhosa ou violenta, pouco importa. Essa comunicação também pode se tornar apropriação do corpo alheio, na medida em que não são fotografadas as partes do corpo tradicionais (o rosto, as mãos), mas fragmentos de carne usualmente proibidos ao olhar fotográfico - os seios, o ventre. Então a câmera não aparece mais como instrumento de comunicação, mas como máquina objetificadora, que se recusa a dialogar ao tornar o outro objeto de um olhar que dele se apodera.

Pataut faz uma cópia de contato de cada filme, e revela as fotografias tiradas sozinho ou em conjunto com as crianças, conforme o seu desejo - algumas têm medo de entrar no laboratório escuro, outras não respeitam as regras e acendem a luz, mas todas ficam impressionadas quando veem a fotografia aparecer no tanque de revelação. As fotos reveladas são entregues às crianças, que delas fazem usos diversos: incluem-nas em seus álbuns pessoais, cedem-nas a álbuns coletivos, apropriam-se delas de forma particular (com abraços, conversas, rasgos, perfurações, recortes, rabiscos, etc.).

Ao final se constitui um arquivo com 85 conjuntos (um para cada criança) de 12 fotos, e um quadro dessas fotos é pendurado em exposição no hospital - como é usual em arteterapia. 


\section{QUEM É O AUTOR DESSAS FOTOGRAFIAS?}

Iterum ergo eos interrogavit quem quaeritis illi autem dixerunt Iesum Nazarenum (Ioannes, $18: 7)^{17}$.

\section{Direito e Fotografia}

Desde os seus primórdios a fotografia representou um problema para a teoria dos direitos autorais. Fundada desde a Convenção de Berna na ideia da criação ${ }^{18}$, por sua vez dependente de uma concepção lockeana da propriedade sobre o trabalho como direito natural de todos os indivíduos, a visão moderna dos direitos subjetivos do autor teve dificuldades em lidar com uma prática artística limitada ao simples aperto de um botão. Em uma perspectiva como essa, se não há trabalho não há criação; e se não há criação não há qualquer direito, moral ou patrimonial, a ser protegido. Neste sentido, Krauss chega até a questionar se a transformação da fotografia de simples registro (em especial o registro topográfico) em discurso estético não teria sido uma elaboração retrospectiva, realizada com o intuito de a legitimar como forma artística:

O material de base do histórico é justamente esse tipo de fotografia, de essência topográfica por natureza e empreendida originalmente em função das necessidades de exploração geográfica, das expedições e dos levantamentos topográficos. Montadas, emolduradas e dotadas de um título, as imagens entram hoje pelo viés do museu no terreno da reconstrução histórica. Podemos agora ler na parede da exposição esses objetos sabiamente isolados de acordo com uma certa lógica, lógica essa que, para legitimá-los, põe ênfase em seu caráter de representação no espaço discursivo da arte (KRAUSS, 2010:43).

Percebe-se claramente a dificuldade inicial do direito em lidar com a fotografia na decisão proferida ainda em 1861 pelo Tribunal de Comércio de Turim, citada por Bernard Edelman. Na ocasião se considerou que não há autoria de processos mecânicos, e só pode haver arte onde "operam o espírito e a imaginação":

Só a máquina age, e o fotógrafo somente aprendeu a pô-la convenientemente em ação [...] e a preparar as operações químicas que devem reproduzir [...]. A sua arte reduz-se a um processo puramente mecânico, no qual pode mostrar mais ou menos habilidade, mas sem que possa ser equiparado aos que professam as belas-artes, nas quais operam o espírito e a imaginação, e algumas vezes o gênio formado pelos preceitos da arte (EDELMAN, 1976:54).

\footnotetext{
${ }^{17}$ Tornou-lhes, pois, a perguntar: A quem buscais? E eles disseram: A Jesus Nazareno (João 18:7).

${ }^{18} \mathrm{Na}$ edição original de 1886, assinada por Bélgica, França, Alemanha, Haiti, Itália, Libéria, Espanha, Suíça, Tunísia e Reino Unido, versão em língua inglesa: "Article 4. The expression 'literary and artistic works' shall include books, pamphlets, and all other writings; dramatic or dramatico-musical works, musical compositions with or without words; works of drawing, painting, sculpture and engraving; litographs, illustrations, geographical charts; plans, sketches, and plastic woks relative to geography, topography, architecture, or science in general; in fact, every production whatsoever in the literary, scientific, or artistic domain which can be published by any mode of impression or reproduction”. A Convenção somente foi promulgada no Brasil pelo Decreto Presidencial 75.699/75, de modo que não há tradução oficial desta primeira edição, que aqui se traduz livremente: "Artigo 4. Os termos "obras literárias e artísticas” abrangem livros, brochuras e outros escritos; obras dramáticas ou dramático-musicais, composições musicais com ou sem palavras; obras de desenho, de pintura, de escultura e de gravura; litografias, ilustrações, mapas geográficos; projetos, esboços e obras plásticas relativos à geografia, topografia, arquitetura ou às ciências; em suma, todas as produções do domínio literário, científico e artístico, que podem ser publicadas por qualquer modo de impressão ou reprodução”.
} 
Neste momento, o próprio aspecto objetivo da imagem resultante da fotografia, em contraposição à subjetividade (elemento essencial daquilo que se pode chamar arte), contribuía para a manutenção da ideia simplificadora de que não havia criação no ato fotográfico. Porém, como explica o próprio Edelman (1976:52), o tempo da resistência ao reconhecimento da fotografia como produção artística não era economicamente neutro. Era o tempo do artesanato, da descoberta tecnológica sem interesse comercial. A captura industrial das técnicas cinematográficas e fotográficas vai produzir uma reviravolta radical: o fotógrafo e o cineasta serão tornados criadores, sob pena de ficar a indústria sem proteção legal.

Com o desenvolvimento da indústria cultural os tribunais progressivamente arrancam a fotografia da máquina e a reinserem no âmbito da subjetividade: a máquina é substituída pela técnica, e passa a ser tratada como mero instrumento de afirmação do trabalho criativo do sujeito-artista; torna-se apenas meio, subordinado à finalidade de criação. Aos poucos o direito promove a subjetivação da máquina, que "perde o seu 'ser' e se torna meio de ser do sujeito" (EDELMAN, 1976:63). A câmera se torna espaço de manifestação de um trabalho humano, reles mediação técnica da valiosa produção criativa do sujeito transcendental.

No entanto, a subjetivação da máquina exige que a fotografia traga inscrita em si a marca pessoal do autor, refletindo a sua personalidade e revelando o seu trabalho pessoal de criação. A criação só pode ser criação de um sujeito, e somente com a incorporação de sua essência subjetiva ao produto é que ele poderá ser considerado digno de proteção jurídica. Desse modo, para que a fotografia possa ser considerada obra intelectual é preciso que ela cumpra ao menos dois requisitos básicos, ligados à ideia fundamental de criação: ela deve ser resultado do trabalho pessoal do autor (e não de processos mecânicos automáticos); ela deve ser resultado de um ato original de sobre-apropriação subjetiva do real (e não de captação objetiva da realidade).

Emblemática dessa percepção é a decisão proferida pelo Tribunal de Alçada de Minas Gerais em ação em que se discutia se o trabalho fotográfico de determinado sujeito constituía criação artística (citada por STAUT, 2006:74). O voto vencido argumentou:

Para que a fotografia se enquadre como obra intelectual protegida, no entanto, exige-se que a mesma possa ser considerada criação artística, portanto verdadeira obra de arte, em vista da escolha do objeto e das condições da execução.

E a ementa do acórdão decidiu:

Não caracteriza obra de arte, a justificar a proteção da lei de Direito Autoral, a fotografia cujo objeto não foi escolhido pelo fotógrafo e em cuja produção não se empregou criatividade (RJTAMG. Belo Horizone: Del Rey, v. 75, ano XXIV, abr./jun. 1999, p. 139).

Como se percebe, o reconhecimento dos direitos do autor na obra fotográfica depende da possibilidade de identificação, na obra, dos elementos básicos justificadores da proteção jurídica da autoria. Sem trabalho pessoal e criação subjetiva não é possível promover a subjetivação da máquina, e o registro da imagem se reduz novamente a puro processo mecânico-químico de exposição de material sensível à luz. 
Compreende-se melhor o interesse jurídico suscitado pela controvérsia acerca da autoria da selfie do macaco. A atribuição da autoria ao fotógrafo David Slater depende de sua capacidade de demonstrar ter concorrido com o seu trabalho pessoal e a sua criatividade subjetiva para a produção da imagem; sem isso, o registro se reduz a puro ato do acaso, insuscetível de proteção moral ou patrimonial.

É por isso que a sua narrativa pessoal faz questão de frisar não só o difícil trabalho pessoal de chegar aos macacos para realizar a foto, mas também a sequência de fatos que originou o seu insight criativo de criar as condições para o registro da selfie. Se for suficientemente convincente, a identificação do responsável por acionar o disparador será irrelevante para o direito; poderia ter sido o macaco, o fotógrafo, o guia, ou até mesmo um processo mecânico automático da própria câmera, regulada para disparar automaticamente. Para o direito, a autoria da foto não decorre do aperto de um botão; decorre do ato precedente de criação intelectual da imagem que será registrada pela câmera.

Dessa perspectiva, o autor de qualquer fotografia é o sujeito do ato criativo. A controvérsia em torno da selfie do macaco se limita, então, à verificação da existência de uma intenção subjetiva prévia ao processo mecânico de registro da foto, reveladora do ato criador do fotógrafo como projeto para a fixação da imagem. Para o direito apenas uma pergunta exige resposta: qual foi a intenção do fotógrafo?

\section{FOTOGRAFICIDADE}

As reflexões acadêmicas sobre a fotografia tendem a não se preocupar exatamente com o ato fotográfico, em si, mas com o sentido social da prática fotográfica. Em sua "pequena história da fotografia" Walter Benjamin (1994a) reflete sobre o impacto da tecnologia na produção artística, analisando as relações entre fotografia e artes plásticas nos anos de desenvolvimento da técnica fotográfica; os ensaios de Susan Sontag (2006) pensam a fotografia como fenômeno cultural, preocupando-se em compreender os efeitos sociais dessa forma particular de visão do real; a coletânea de estudos reunida por Pierre Bourdieu (2003) examina as condições de recepção social da fotografia, levando em consideração os seus usos e funções comunitárias.

A análise de Roland Barthes (1984) está mais diretamente ligada ao próprio ato de produção fotográfica: o autor não se interessa pela fotografia como ação social, mas pela identificação do elemento que a define como manifestação artística. Para isso, busca a essência da fotografia em seu referente; é no objeto fotografado que encontra os elementos estéticos fundamentais de uma foto determinada: de um lado, o studium, essa espécie de "interesse sensato" que faz o espectador sentir-se em harmonia com as intenções do fotógrafo (BARTHES, 1984:48); de outro lado o punctum, um detalhe pungente capaz de atribuir à foto um suplemento de significado, "partindo da cena como uma flecha” e transpassando o espectador em seu âmago (BARTHES, 1984:69). 
Não sendo fotógrafo, mas semiólogo, Barthes adota em sua análise a perspectiva do Spectator, o sujeito que olha. Com isso, descarta o aspecto maquínico da prática fotográfica e constrói uma teoria amadora da fotografia: não porque na fotografia amadora só importe o olhar do fotógrafo; mas porque para a percepção amadora da fotografia só o olhar existe, e a mecânica do ato fotográfico permanece oculta pelo véu de um processo semiautomático - de calibração mecânica do equipamento, codificação eletrônica no sensor digital (ou física na película fotossensível), revelação química da imagem, etc. Assim, dilui a riqueza da experiência fotográfica no significado atribuído ao seu conteúdo, ignorando a sua própria intuição inicial de perceber que o órgão do fotógrafo não é o olho, mas o dedo:

Estranhamente, a única coisa que suporto, de que gosto, que me é familiar, quando me fotografam, é o ruído da máquina. Para mim, o órgão do Fotógrafo não é o olho (ele me terrifica), é o dedo: o que está ligado ao disparador da objetiva, ao deslizar metálico das placas (quando a máquina ainda as tem). Gosto desses ruídos mecânicos de uma maneira quase voluptuosa, como se, da Fotografia, eles fossem exatamente isso - e apenas isso - a que meu desejo se atém, quebrando com seu breve estalo a camada mortifera da Pose (BARTHES, 1984:29).

Desse modo, a instigante abordagem barthesiana também não consegue evitar recair na perspectiva da intencionalidade, compartilhando com as abordagens sociológicas a mesma postura de enfatizar elementos exteriores ao próprio ato fotográfico (dessa vez, não mais os seus efeitos sociais, mas o conteúdo da imagem produzida), o que o impede de compreender a especificidade estética da fotografia em relação a qualquer outro tipo de produção imagética.

A adequada percepção da singularidade da fotografia exige outro tipo de abordagem: uma abordagem que desloque o olhar dos elementos externos e internos ao fazer fotográfico para as particularidades do próprio ato fotográfico; que tome a fotografia como "acontecimento discursivo" (FOUCAULT, 2005:98), esvaziando-a de todo significado transcendental a priori e restituindo-a à sua materialidade própria. Nessa abordagem a atenção pode se deslocar do conteúdo ou dos efeitos da prática fotográfica para a ordem do discurso fotográfico, para o conjunto de procedimentos que organizam a limitação e a constituição de significados na prática fotográfica, o que permite compreender as condições de produção estética do discurso fotográfico. Trata-se, como defende François Soulages, de "passar de uma concepção humanista a uma concepção materialista da fotografia" (2010:132).

É partindo dessa perspectiva que Soulages desenvolve o conceito de fotograficidade, por meio do qual se refere à singularidade da fotografia e à própria essência da estética fotográfica; trata-se de analisar aquilo que é especificamente fotográfico em toda fotografia possível, independentemente do seu conteúdo, estilo ou sentido social. Para o autor essa especificidade será encontrada na articulação entre o irreversível e o inacabável, entre a 
irreversível obtenção negativa ${ }^{19}$ de um momento jamais repetível e o interminável trabalho de sua reelaboração para a e na apreciação estética. Esclarece:

A fotograficidade caracteriza-se pela articulação surpreendente e única do irreversível e do inacabável, mais precisamente da irreversível obtenção generalizada do negativo e do inacabável trabalho com esse negativo. A fotografia é, portanto, a articulação da perda e daquilo que permanece: perda do objeto a ser fotografado, do momento que compreende o ato fotográfico e do processo de obtenção generalizada irreversível do negativo, em resumo, do tempo e do ser passados; permanência constituída por esse número infinito de fotos que podem ser feitas a partir de um negativo, em resumo, por essas imagens rebeldes e enigmáticas. Uma tríplice estética da fotografia pode então ser iniciada: a do irreversível ou da perda, a do inacabável ou da permanência e a da articulação do irreversível e do inacabável ou da perda e da permanência - pois a estética do inacabável trabalho com o negativo se articula com a da inacabável recepção de uma obra de arte em geral e de uma obra fotográfica em particular (SOULAGES, 2010:243).

É na combinação de articulações possíveis entre o registro irreversível e a intervenção inacabável que se encontra o fundamento de apreciação estética de toda fotografia - familiar ou profissional, encenada ou documental, como obra ou individual. Mas uma concepção materialista de fotografia exige ressaltar que "irreversível" e "inacabável" não são aspectos imanentes de um objeto fotográfico nascido ex nihilo da decisão estética tomada por uma sensibilidade artística transcendental; a articulação entre o irreversível e o inacabável é resultado de um trabalho concreto de fabricação de um material (a foto), composto necessariamente por ao menos quatro etapas distintas: o ato fotográfico, a obtenção do negativo, o trabalho sobre o negativo e a recepção da foto - que ainda podem ser precedidas por outras duas: a montagem e iluminação da cena e a regulação da máquina fotográfica.

A produção do irreversível tem início com o ato fotográfico: após a produção da cena e a regulação da máquina por um processo voluntário e manual ou espontâneo e automático (de composição e iluminação da cena, definição da abertura e velocidade do obturador e do grau de sensibilidade à luz do filme ou sensor digital), o fotógrafo aperta o disparador e abre o obturador da câmera; o filme virgem é exposto à luz da cena e registra os padrões captados pelo obturador.

O segundo passo é a obtenção do negativo, composto de cinco momentos: a revelação propriamente dita, que transforma o halogeneto de prata da emulsão do filme em prata metal, o banho interruptor, a fixação, a lavagem e a secagem. Ao final do processo se obtém um negativo que será a matriz das fotos futuras, e que não será mais transformado mesmo com a passagem da luz através dele ${ }^{20}$.

\footnotetext{
${ }^{19}$ A fotografia digital não desmente essa conclusão. Como explica Soulages (2010:134), na fotografia digital passamos da lógica da marca (sobre o filme fotossensível) para a lógica da simulação (de uma imagem matriz com base em um cálculo matemático), mas permanece a relação temporal com um real temporal - e, portanto, irreversível.

${ }^{20}$ Nas câmeras digitais os processos químicos e mecânicos são substituídos por um processo eletrônico, no qual um aparelho semicondutor registra a luz eletricamente através de uma gradação em volts, medindo a descarga elétrica gerada pela luz. $\mathrm{O}$ microcomputador embutido na câmera transforma essa informação em dados digitais, que são posteriormente convertidos eletronicamente em uma imagem.
} 
Então começa a etapa inacabável, com o trabalho sobre o negativo que o transforma em foto. Após escolhida a tomada a ser revelada ela é posta em um chassi e exposta à luz sobre um papel sensível; esse papel é revelado e depois imerso num banho interruptor, depois fixado, depois lavado e, por fim, seco; tem-se então a foto $^{21}$. Como recorda Soulages (2010:141), diante do negativo o fotógrafo se apresenta ao mesmo tempo como receptor, intérprete e criador: pode trabalhar o negativo para a produção de fotos; pode delegar esse trabalho a outra pessoa; ou pode deixar intacto o negativo.

Nos três casos há interpretação e posicionamento estético. Mas a interpretação do fotógrafo é apenas o primeiro elo de uma longa cadeia de recepções que continuarão o trabalho de interpretação da foto, atuando como suas recriações ou cocriações. A contextualização da foto pelo Spectator é decisiva na atribuição de significados a ela, pois somente a sua localização em um ambiente semântico específico pode lhe conferir um efeito estético determinado (o punctum de que fala Barthes). Como intuía Walter Benjamin, com precisão, é a legenda a parte mais essencial da fotografia:

Mas o que nem Wiertz nem Baudelaire compreenderam, no seu tempo, são as injunções implícitas na autenticidade da fotografia. Nem sempre será possível contorná-las com uma reportagem, cujos clichês somente produzem o efeito de provocar no espectador associações linguísticas. A câmara se torna cada vez menor, cada vez mais apta a fixar imagens efêmeras e secretas, cujo efeito de choque paralisa o mecanismo associativo do espectador. Aqui deve intervir a legenda, introduzida pela fotografia para favorecer a literalização de todas as relações de vida e sem a qual qualquer construção fotográfica corre o risco de permanecer vaga e aproximativa. [...] Já se disse que 'o analfabeto do futuro não será quem não sabe escrever, e sim quem não sabe fotografar'. Mas um fotógrafo que não sabe ler suas próprias imagens não é pior que um analfabeto? Não se tornará a legenda a parte mais essencial da fotografia? (BENJAMIN, 1994a:107).

\section{QUEM É O AUTOR DESSA FOTOGRAFIA?}

Se a essência da estética fotográfica se encontra nas articulações possíveis entre o irreversível e o inacabável, a pergunta sobre a autoria de qualquer fotografia não deve se preocupar somente com a "intenção" do fotógrafo ao registrar a imagem; em vez disso deve se referir, necessariamente, ao responsável pelo trabalho concreto de produção material do registro irreversível e da ressignificação inacabável. Ocorre que esse trabalho depende do encadeamento de uma série de ações concretas independentes, o que faz com que a resposta à pergunta formulada dependa necessariamente da resposta a ser dada a outras perguntas, que lhe antecedem:

$$
\begin{aligned}
& \text { Quem monta a cena? } \\
& \text { Quem regula a máquina? } \\
& \text { Quem aperta o disparador? } \\
& \text { Quem produz o negativo? } \\
& \text { Quem revela a fotografia? }
\end{aligned}
$$

\footnotetext{
${ }^{21}$ Nas câmeras digitais essa etapa do processo também é realizada eletronicamente, primeiro em programas de edição e tratamento de imagens (como o Photoshop e o Lightroom), e depois com a conversão dos dados eletrônicos em papel impresso através do trabalho de uma impressora conectada a um computador.
} 
Quem contextualiza a foto?

Ecce homo. Eis o autor.

Ut cognoscatis quia in eo nullam causam invenio et purpureum vestimentum et dicit eis ecce homo (Ioannes, 19:5) ${ }^{22}$.

\section{A Aporia da Autoria}

Em 1935 Walter Benjamin assiste, entre perplexo e entusiasmado, à intromissão da tecnologia em um mundo até então imune ao processo de desencantamento: o mundo da cultura. O desenvolvimento de novas técnicas de reprodução modifica as formas de sensibilidade estética, transforma a arte tradicional e cria novas formas artísticas - como a fotografia e o cinema.

Como explica Benjamin (1994b:172), nas obras fotográficas e cinematográficas a reprodutibilidade técnica não é apenas uma condição externa para a difusão maciça do produto, como ocorre na literatura ou na pintura: é condição inerente à própria produção artística. Fotografia e cinema são, em sua essência, técnicas de reprodução; e ao adotarem a reprodutibilidade como condição de possibilidade da criação estética, radicalizaram a refuncionalização da produção artística em ação desde o início da modernidade, fazendo com que a relevância da obra de arte fosse progressivamente desvinculada de seu valor de culto e passasse a ser aferida por seu valor de exposição de massa.

A transformação das formas de criação e sensibilidade artística reflete as profundas mudanças ocorridas nas condições materiais de produção das sociedades ocidentais desde o século XVIII. A técnica emancipada se confronta com a sociedade moderna sob a forma de uma segunda natureza, diante da qual somos obrigados a aprender. Nesse contexto, a foto e o filme contribuem para "exercitar o homem nas novas percepções e reações exigidas por um aparelho técnico cujo papel cresce cada vez mais em sua vida cotidiana”, fazendo do gigantesco aparelho técnico do nosso tempo o objeto das próprias inervações humanas (BENJAMIN, 1994b:174).

Considerando como cinema e fotografia refletem as condições do nosso tempo tanto no modo de produção quanto na forma do produto, a estética cinefotográfica se afirma, por natureza, como produção industrial e criação da coletividade. E o é em duplo sentido: porque é necessariamente produto criado para uma coletividade, sendo dirigido a uma recepção coletiva; mas também porque é necessariamente criado por uma coletividade, um enorme conjunto de técnicos e especialistas que mesmo o mais aficcionado fã das premiações do Oscar terá dificuldade em enumerar. Benjamin argumenta:

A reprodutibilidade técnica do filme tem seu fundamento imediato na técnica de sua produção. Esta não apenas permite, da forma mais imediata, a difusão em massa da obra cinematográfica, como a torna obrigatória. A difusão se torna obrigatória, porque a produção de um filme é tão cara que um consumidor, que poderia, por exemplo, pagar por um quadro, não pode mais pagar um filme. O filme é uma criação da coletividade. Em 1927, calculou-se

\footnotetext{
${ }^{22}$ Quando Jesus veio para fora, usando a coroa de espinhos e a capa de púrpura, disse-lhes Pilatos: "Eis o homem!" (João, 19:5). vol. 08, nº. 04, Número Especial. 2015.pp. 2233-2260 
que um filme de longa metragem, para ser rentável, precisaria atingir um público de nove milhões de pessoas (BENJAMIN, 1994b:172).

É claro que o argumento de Benjamin tem limitações. Se em 1927 o público de nove milhões de pessoas era condição necessária à compensação dos custos proibitivos de uma obra cinematográfica, o próprio progresso tecnológico tornou obsoleta essa exigência financeira. As novas técnicas de gravação digital permitem que se produza um blockbuster como A Bruxa de Blair, por exemplo, por apenas US\$22.500,00. Além disso, quando transportada para o campo da fotografia a afirmação perde completamente o sentido: os instrumentos de produção fotográfica se tornaram acessíveis a ponto transformarem-na em uma prática não só doméstica, mas também cotidiana e potencialmente ilimitada - especialmente depois que a fotografia digital eliminou os custos de aquisição de filmes e depois que os canais de reprodução online (Flickr, Instagram, Facebook) eliminaram os custos de revelação.

Contudo, se a progressiva redução dos custos de produção tornou desnecessária, em termos financeiros, a reprodução massificada do cinema e da fotografia, ela não suprimiu a essência coletiva da produção artística cinematográfica e fotográfica, necessariamente obrigada a contar com o trabalho coletivo de uma série de especialistas em diversas áreas do conhecimento para a obtenção da obra como resultado final. Ainda que na "versão amadora" da fotografia e da filmagem esse trabalho não apareça, permanece lá, oculto em processos semiautomatizados de calibração eletrônica, de disponibilização de filtros e presets para inserção na imagem digital e de revelação física ou online das fotografias ${ }^{23}$ (realizados por profissionais especializados em ótica, eletrônica, programação de softwares, webdesign, etc.). Reflete Benjamin:

Ao contrário do ator de teatro, o intérprete de um filme não representa diante de um público qualquer a cena a ser reproduzida, e sim diante de um grêmio de especialistas - produtor, diretor, operador, engenheiro do som ou da iluminação, etc. - que a todo momento tem o direito de intervir. Do ponto de vista social, é uma característica muito importante. A intervenção de um grêmio de técnicos é com efeito típica do desempenho esportivo e, em geral, da execução de um teste (BENJAMIN, 1994b:178).

Além disso, mais interessante do que avaliar em termos financeiros a produção coletiva do cinema e da fotografia é constatar a natureza coletiva da própria experiência estética cinematográfica e fotográfica, produzida não só para um consumo massificado mas, principalmente, para uma apreciação estética coletiva:

O decisivo, aqui, é que no cinema, mais que em qualquer outra arte, as reações do indivíduo, cuja soma constitui a reação coletiva do público, são condicionadas, desde o início, pelo caráter coletivo dessa reação. Ao mesmo tempo que essas reações se manifestam, elas se controlam mutuamente. De novo, a comparação com a pintura se revela útil. Os pintores queriam que seus quadros fossem vistos por uma pessoa, ou poucas. A contemplação simultânea de quadros por um grande público, que se iniciou no século XIX, é um sintoma

\footnotetext{
${ }^{23} \mathrm{O}$ reconhecimento da coprodução artística nesse trabalho oculto em processos automatizados aparece com clareza na prática adotada por serviços de compartilhamento de imagens como o Instagram, por exemplo, de exigir a concessão de uma "licença mundial, sublicenciável,e transferível, não exclusiva e livre de royalties ou qualquer pagamento" como condição para o compartilhamento de qualquer imagem em sua rede (Instagram, Termos de Uso, Direitos, 1 - disponível em 16 de setembro de 2014 no sítio <http://instagram.com/about/legal/terms/\#>).
} 
precoce da crise da pintura, que não foi determinada apenas pelo advento da fotografia, mas independentemente dela, através do apelo dirigido às massas pela obra de arte (BENJAMIN, 1994b:188).

Cinema e fotografia são produções artísticas criadas para uma apreciação coletiva, não individual. É curioso perceber como a redução dos custos de produção não eliminou o caráter coletivo do consumo de obras fotográficas e cinematográficas; pelo contrário, nas últimas décadas assistimos a uma multiplicação dos mercados de comercialização de fotos e filmes, que apenas intensificou o apelo dirigido às massas e o caráter coletivo da experiência estética correspondente - em pôsteres, jornais, revistas, bancos públicos de imagens, websites, salas de cinemas, televisão aberta e a cabo, locação e venda de DVDs e blu-rays, streaming, licenciamento de produtos, etc.

Essa apreciação coletiva não é mero consumo passivo da produção da indústria cultural; ela integra o processo de criação artística e compõe a essência da fotograficidade, pois faz parte da "longa cadeia de recepções" que inserem a obra de arte em um ambiente semântico específico, dotando-a de um significado particular e de um efeito estético determinado. Se "a legenda é a parte mais essencial da fotografia" (BENJAMIN, 1994a:107), é inevitável reconhecer a coletividade como coautora da obra fotográfica e cinematográfica, na medida em que é o público o responsável por "inserir a legenda" e continuar a interpretação somente iniciada pelo autor, em um trabalho de permanente recriação da obra de arte.

Já em 1935 Benjamin pressagiava que a diferença essencial entre autor e público estava a ponto de desaparecer (1994b:184). Profetizava a morte do autor romântico tendo diante de si o seu espectro, sem perceber que ela já havia ocorrido; não pelo caráter intercambiável das posições de autor e público em um mundo cada vez mais especializado, mas porque na cultura de massa o trabalho de contextualização realizado pelo público havia se tornado condição inerente à própria produção artística, sem a qual ela seria privada da maior parte da sua expressividade estética.

Hoje, diante do cadáver decomposto que agora observamos, já não parece precipitada a declaração de óbito da própria ideia de autoria. $\mathrm{O}$ artista beethoveniano, que trabalhava isolado encerrado por anos na solidão de seus aposentos, até finalmente emergir do exílio acompanhado da obra-prima que expressava a pureza de sua subjetividade atormentada, morreu ${ }^{24}$. O desenvolvimento tecnológico fez com que o reconhecimento assertivo de uma "autoria compartilhada" perdesse o ar de filantropia da empoeirada crítica política ao "individualismo dos tempos modernos", ou de gratidão magnânima ao familiar compreensivo sem cuja colaboração o artista seria obrigado a "abdicar da vocação" para lavar suas meias, para se tornar a simples descrição factual do modo como se produz obras intelectuais em uma sociedade marcada pelo colaborativismo em rede e pelo consumo de massa. A própria arte contemporânea não deixou de se apropriar das novas condições de produção, promovendo uma

\footnotetext{
${ }^{24}$ Se é que algum dia realmente existiu, já que o próprio Beethoven, símbolo máximo da originalidade da autoria individual, costumava se apropriar de trechos completos de obras de Haydn e Mozart na composição de suas sinfonias - um pouco menos "individuais" e "subjetivas" do que se costuma acreditar.
} 
completa subversão das noções clássicas de autoria individual mesmo nas artes tradicionais como a pintura, a escultura e a literatura - com a pop art de Andy Warhols, o ready made de Marcel Duchamp, a literatura-pastiche de William Burroughs ${ }^{25}$, etc.

Em uma sociedade como essa, a autoria somente pode se constituir como aporia. Um processo complexo como é a produção artística na sociedade de massas, marcado pela participação coletiva em todas as fases do processo produtivo, tem a sua autoria marcada por uma indecidibilidade: se a autoria da fotografia deve ser atribuída ao indivíduo que monta a cena, regula a máquina, aperta o disparador, produz o negativo, revela a fotografia, interpreta e contextualiza a foto, a quem pertence a autoria quando cada uma dessas etapas é marcada pela intervenção coletiva de um conjunto de técnicos e intérpretes anônimos que, com seu trabalho criativo, contribui igualmente para a produção da obra? Nenhum deles pode ser considerado, sozinho, autor; mas todos são igualmente indispensáveis na sua criação. A impossibilidade de se fornecer qualquer resposta definitiva a esta pergunta demonstra as insuficiências da própria pergunta: a fragmentação da produção artística contemporânea esquartejou o corpo místico do transcendental autor moderno.

\section{E COM ISSO O AUTOR MORREU}

Et clamans voce magna Iesus ait Pater in manus tuas commendo spiritum meum et haec dicens exspiravit (Lucas, 23:45) ${ }^{26}$.

\section{As Crianças de Aubervilliers e o Autor-Intérprete}

Nas fotos das crianças de Aubervilliers se manifesta em plenitude a natureza coletiva da produção fotográfica. Desde o início do trabalho o ensaio se caracteriza como projeto coletivo: a iniciativa é da equipe do hospital; a sua forma geral é elaborada pelo fotógrafo profissional, que calibra a câmera e estrutura a atividade; as fotografias são realizadas pelas crianças internadas; a revelação envolve o fotógrafo que coordenou a atividade e as crianças que realizaram as fotografias; a exposição é organizada pelo fotógrafo, mas no próprio hospital psiquiátrico, como parte das atividades terapêuticas realizadas pela equipe de médicos; e o contexto semântico das fotos é construído coletivamente pelo fotógrafo, pelas crianças, por seus familiares, pelos médicos, pelo público que visita a exposição e pelo próprio trabalho de produção fotográfica.

\footnotetext{
${ }^{25}$ Um exemplo mais contemporâneo e curioso, embora mais banal, é o livro intitulado I'm writing a novel, de "autoria" de Cory Arcangel. A obra complexifica as concepções de autoria compartilhada ao se limitar a catalogar uma série de tweets de indivíduos que diziam estar escrevendo um romance na rede social Twitter, tendo sido objeto de reportagem recente pela revista New Yorker - disponível em 8 de agosto de 2014 no sítio <http://www.newyorker.com/culture/cultural-comment/working-novel-tweetingwriting $>$.

${ }^{26}$ Jesus bradou em alta voz: "Pai, nas tuas mãos entrego o meu espírito". Tendo dito isso, expirou. (Lucas, 23:45).
} 
Como explica François Soulages (2010:169), os elementos que conduzem essas fotografias do plano do registro documental para o plano artístico, definindo a expressividade estética da obra e a sua riqueza, não são as imagens registradas, mas os atos e ações fotográficas muito particulares que as geraram e as acompanharam. Se é verdade que as fotos extraem parte de sua força do enquadramento original, é verdade também que a maior parte do significado estético deste enquadramento decorre do fato de sabermos que ele traduz o olhar particular de crianças internadas em um hospital psiquiátrico. Retirar as fotografias do campo da intencionalidade de Marc Pataut para incluí-las no campo do olhar de alteridade das crianças internadas é o que lhes atribui o surplus de expressividade que atrai o olhar, dando-lhes significado artístico.

O que importa não são as fotos tiradas, mas o próprio ato fotográfico, que se apresenta como fim em si mesmo. Com isso a ação fotográfica ultrapassa o mero trabalho técnico de produção de imagens para se tornar relação interpessoal de multiplicação afetiva. Nas palavras de Soulages, "o importante não é mais fazer fotos de pessoas, mas trabalhar com elas a fotografia. A fotografia é quase um pretexto para ter uma história com pessoas; em todo caso, sem essa história, a foto não vale nada nem estética nem existencialmente" (SOULAGES, 2010:175).

O caso ilumina com fulgor o local obscuro onde ocorre a gênese de toda estética fotográfica; se a sua essência está na fotograficidade como eterna relação entre o irreversível e o inacabável, as crianças de Aubervilliers nos obrigam a perceber que o eixo dessa relação jamais será encontrado no campo da intencionalidade do autor transcendental ou no produto imagético obtido tecnicamente, mas somente na performance do próprio ato fotográfico. A força das fotos realizadas pelas crianças não surge da reportagem descritiva ou da composição das imagens, mas da poesia inerente ao próprio ato fotográfico, tornado acontecimento:

O instante do fotográfico é totalmente supervalorizado: é um instante de violência, de intensidade que se destaca dos outros instantes do tempo. Não é considerado como um meio, mas como um fim em si - o que nos aproxima da performance ou do happening: $\mathrm{o}$ ato fotográfico - portanto, fotografar - constitui um acontecimento; não é o acontecimento que é tomado em foto, é a tomada de foto que é acontecimento, não o "isso existiu" objetivante de Barthes, mas o "it happens" subjetivante e que torna existencial a vida de um homem sem qualidade: "isto se passa, isto acontece" e não "isto permanecerá" nem "isto terá sido" (SOULAGES, 2010:174).

Se mesmo assim Soulages pode atribuir a esse conjunto de fotografias alguma autoria, isso ocorre um pouco pelo peso da tradição e pelas limitações da linguagem, e muito por uma subversão da própria concepção tradicional de autoria artística. Nessa nova concepção a autoria não se liga a um ato de criação ex nihilo, mas a um trabalho de contextualização da obra que permite que lhe seja atribuído algum significado estético, transportandoa do sem-arte à arte. A poesia do ato fotográfico não é construída sozinha pelo dedo que aperta o botão, mas principalmente pelos observadores, que interpretam as fotografias e produzem, a partir delas, novas cargas afetivas:

Também falar de "criação" (não, evidentemente, no sentido de uma creatio ex nihilo) para a produção das fotos dessas crianças é legítimo, não tanto porque essa produção não é padronizada mas nova, quanto porque Pataut é o coautor e o cocriador dessas fotos. É por isso que, quando desse trabalho, ele é artista por seu fazer e vol. 08, nº. 04, Número Especial. 2015.pp. 2233-2260 
principalmente por seu ser: ele é o artista, as crianças não o são, mas suas fotos podem, entretanto, passar do semarte à arte. Essa é a importância do inacabável da fotograficidade: a fotografia não se reduz ao ato fotográfico instantâneo, mas compreende também a ação fotográfica e o metafotográfico; essa é a força da recepção e da interpretação.

Quem fez essas fotos? O acaso? As crianças? Pataut? Nenhuma das respostas é inteiramente satisfatória. É preciso, ao mesmo tempo em que se reconhece a especificidade de cada interveniente, ousar pensar problematicamente a pluralidade de autores - sendo a noção de autor, por consequência, esvaziada de qualquer relação com a autoridade [...]. Em contrapartida, podemos reconhecer que os autores da transformação em obra, aqui, são, certamente e em certa medida, os observadores, mas sobretudo o intérprete principal, Marc Pataut, que, ao mesmo tempo, instalou o metafotográfico, as ações fotográficas e os atos fotográficos e trabalhou os negativos. Essa transformação em obra depende, evidentemente, de seus critérios de escolha, eles próprios trabalhados por seu tempo, sua cultura e seu inconsciente. Ela é aqui a condição da transformação em arte, mas a transformação em arte está teleologicamente na transformação em obra: teleologia afirmada do intérprete (SOULAGES, 2010:178).

Desse modo, é somente como intérprete que Pataut pode ser considerado, em alguma medida, autor da obra. O que importa não é o seu trabalho técnico-profissional de fixação e revelação das imagens, que em nada contribui para a criação de valência afetiva; a importância de sua contribuição se mede exclusivamente por sua sensibilidade estética de perceber arte nas fotos realizadas, permitindo que ela se manifeste em toda a sua potência. Mas reconhecer o criador da legenda como autor nos obriga a reconhecer também outros coautores ao lado do fotógrafo que a redigiu; afinal, ainda que tenha sido ele a realizar o trabalho de organização em obra, não é somente a organização que produz o contexto semântico das fotografias, mas também o tratamento médico e psicológico, também as relações afetivas de pais e familiares, também a vontade particular das crianças de produzir arte.

E ainda um último passo: se os verdadeiros autores da obra de arte são os seus observadores, a produção artística não é somente coletiva. A autoria está distribuída pela massa anônima e disforme de intérpretes e apreciadores, que contextualiza semanticamente a obra e lhe atribui significados capazes de gerar afetos recíprocos, compartilhando-os de modo relacional - pois o afeto é sempre relacional. Se o autor é o observador, a própria natureza da obra de arte, reforçada pela reprodutibilidade técnica e pelos meios de comunicação de massa, nos conduz para além da autoria coletiva.

\section{PARA ALÉM DE UMA COLETIVIDADE, O AUTOR É A MULTIDÃO}

Ubi enim sunt duo vel tres congregati in nomine meo, ibi sum in medio eorum. (Matthaeum, 18:20) ${ }^{27}$.

\footnotetext{
27 Porque, onde estiverem dois ou três reunidos em meu nome, aí estou eu no meio deles. (Mateus, 18:20).
} 


\section{A Selfie do Macaco e o Autor-Multidão}

Em 2004 a editora britânica Oxford Dictionaries resolveu instaurar uma nova tradição: eleger a cada ano a "Palavra do Ano dos Dicionários Oxford", escolhida entre as palavras que tivessem atraído maior interesse popular no período e fossem capazes de refletir o ethos, a atmosfera ou as preocupações daquele ano em $\operatorname{particular}^{28}$. As candidatas são extraídas inicialmente do Oxford Dictionaries New Monitor Corpus, um programa de pesquisa capaz de coletar mensalmente cerca de 150 milhões de palavras inglesas em uso na rede mundial, identificando diariamente palavras novas e emergentes e examinando diferenças de geografia, registro e frequência de uso. $\mathrm{O}$ arquivo sofre o acréscimo de sugestões dos editores e de redes sociais, e a seleção final é realizada pelo grupo de lexicógrafos, consultores, editores e publicitários que compõem a equipe da editora. A tradição permaneceu relativamente ignorada pela mídia até o ano de 2013, quando o software de pesquisa revelou que o uso da palavra selfie havia sofrido um aumento de $17.000 \%$ no período de um ano, e a sua eleição como "palavra do ano" foi noticiada em jornais de todo o mundo.

A palavra selfie é definida pelo Oxford English Dictionary como "uma fotografia que alguém tirou de si mesmo, tipicamente realizada com um smartphone ou uma webcam e carregada em uma rede social" ${ }^{29}$. Segundo a editora, a origem da palavra pôde ser rastreada até o ano de 2002, quando foi utilizada como legenda de uma foto postada em um fórum australiano de discussão online:

2002 ABC Online (forum posting) 13 Sept.

Um, drunk at a mates 21 st, I tripped ofer [sic] and landed lip first (with front teeth coming a very close second) on a set of steps. I had a hole about $1 \mathrm{~cm}$ long right through my bottom lip. And sorry about the focus, it was a selfie ${ }^{30}$.

\footnotetext{
28 "The Oxford Dictionaries Word of the Year is a word, or expression, that we can see has attracted a great deal of interest during the year to date. Every year, candidates for Word of the Year are debated and one is eventually chosen that is judged to reflect the ethos, mood, or preoccupations of that particular year and to have lasting potential as a word of cultural significance". A explicação e o processo de seleção são explicados no website da editora, e estão disponíveis em 20 de outubro de 2014 no sítio eletrônico <http://blog.oxforddictionaries.com/word-of-the-year-faq/>.

${ }^{29}$ Disponível em 19 de novembro de 2013 no sítio eletrônico <http://blog.oxforddictionaries.com/2013/11/word-of-the-year2013-winner/>.

30 "Hã, bêbado no aniversário de 21 anos de um amigo, tropecei e caí de boca (com os dentes da frente em seguida) em uma escadaria. Fiquei com um buraco de quase $1 \mathrm{~cm}$ no meu lábio inferior. E desculpem pelo foco, foi uma selfie" (tradução livre disponível em 19 de novembro de 2013 no sítio eletrônico <http://blog.oxforddictionaries.com/2013/11/word-of-the-year2013-winner/>).
} 


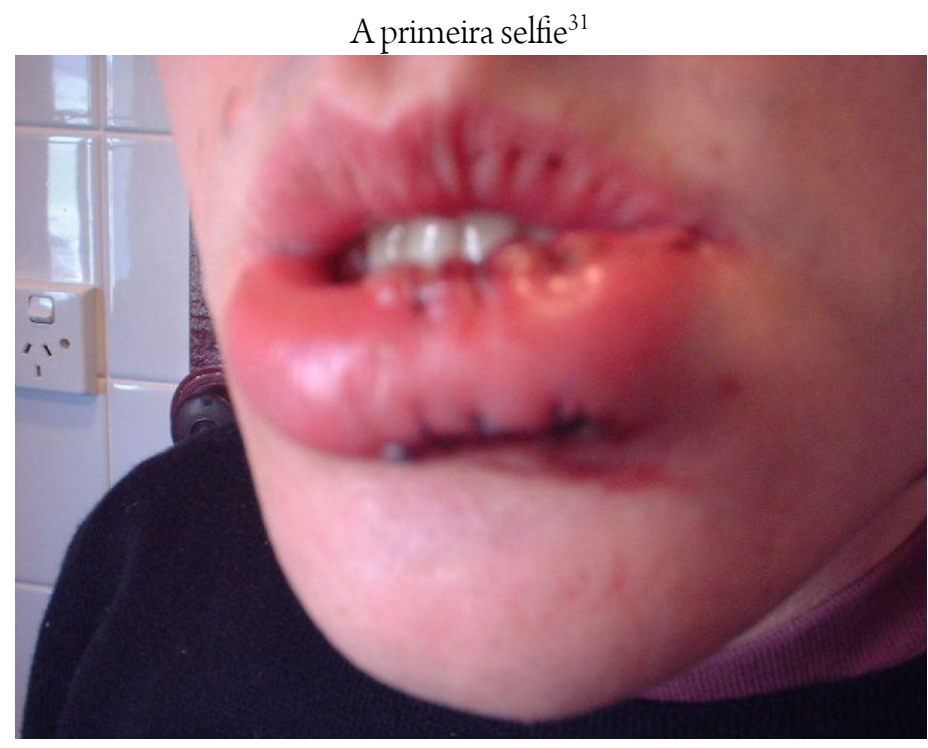

Como se percebe, uma selfie não é exatamente um autorretrato. Difere dele quanto à técnica, ao suporte, às finalidades, ao resultado e à circulação, e reflete modos distintos de percepção de si, correspondentes a situações históricas e culturais peculiares.

O autorretrato é um gênero pictórico desenvolvido no Renascimento, em um contexto de revalorização filosófica do homem diante da natureza e da religiosidade que orientavam toda a vida medieval. O estabelecimento gradual de uma subjetividade individual em substituição ao estatuto pessoal corporativo forma um ambiente propício à proliferação do retrato como instrumento de afirmação da identidade (agora individual) dos membros da nobreza tradicional e da burguesia emergente. O subgênero do autorretrato apenas enfatiza essa tendência, permitindo que o artista expresse a sua própria individualidade autoral, explicitando na pintura as suas características físicas como reflexo simbólico de uma profunda interioridade moral. Desse modo, é resultado de um processo lento e insistente de reflexão do artista sobre si, imposto pelo processo de subversão dos papeis sociais tradicionais ocorrido nos primórdios da modernidade.

Mas se o autorretrato descende na linha materna da nova sensibilidade moderna, tem como pai o desenvolvimento tecnológico: foram as novas técnicas de produção de espelhos com base no amálgama de mercúrio e estanho, desenvolvidas ao final do século XV em Florença e aperfeiçoadas pelos vidreiros venezianos, que tornaram possível a produção de espelhos mais baratos e transparentes e permitiram que a reflexão moral fosse complementada pelo reflexo físico, viabilizando tecnicamente a expressão imagética da subjetividade moral do artista.

A expressão selfie não é somente uma gíria inventada pela juventude para se referir à mesma realidade. A nova palavra se refere a um fenômeno estético distinto, que traduz um novo modo de representação de si e é

\footnotetext{
${ }^{31}$ Disponível em 24/10/2014 no sítio eletrônico <http:/ / www.abc.net.au/news/image/5102578-4x3-940x705.jpg>. vol. 08, no. 04, Número Especial. 2015.pp. 2233-2260
} 
resultado do desenvolvimento de novas condições materiais de produção de subjetividades: a selfie é um modo original de relação dos indivíduos com a sua imagem, em um contexto de celebração de identidades móveis permanentemente reconstruídas a partir dos critérios do olhar do outro. Nesse sentido, atua como panóptico inverso, edifício virtual criado por uma individualidade fragmentada para exibir à coletividade a sua adequação aos padrões flexíveis estabelecidos pela normalização modulatória da sociedade de controle - nos vários papéis sociais dela exigidos: na academia, na "balada", no trabalho, na escola, no voluntariado, nas férias, na viagem, na família, etc.

Assim, diferentemente do autorretrato, a selfie não decorre de um longo processo de autorreflexão sobre a interioridade moral do artista. A selfie não busca ou constrói uma subjetividade individual, mas a esfacela, exibindo a adaptabilidade orgânica do indivíduo a uma subjetividade múltipla, nômade, modular e desarticulada não mais "adaptada", mas "adaptável” às recombinações exigidas pela sociedade pós-industrial. É por isso que a selfie é sempre o registro imediato de um momento, que deve ser simultaneamente extraordinário e cotidiano: extraordinário na representação do nomadismo do sujeito múltiplo em sua adaptação às mais diversas situações sociais; mas também cotidiano, pelo caráter necessariamente comum e usual de tantas situações diversas, que devem compor a "vida normal" não só do autor da selfie, mas também do ponto de alteridade de onde provém o olhar a partir do qual se constitui a sua subjetividade esfacelada, e que nela se reconhece. A própria estética da selfie o demonstra: sempre o mesmo rosto, expressão facial sorridente em primeiro plano, sobre o plano de fundo intercambiável - a torre Eiffel, o prédio da faculdade, o espelho da academia, o restaurante, indicando: como você, eu também estive lá!; como você, eu também fiz isso!; como você, eu também sou uma subjetividade modulável!

É claro que para ser capaz de expressar significados tão peculiares o novo gênero também depende de um suporte tecnológico que torne possível a sua produção e exposição: uma câmera portátil o suficiente para estar sempre à mão; técnicas de exibição imediata e substituição permanente das fotografias realizadas; um público que possa avaliar constantemente o desempenho do sujeito fragmentado quanto à sua flexibilidade e adaptabilidade. Não é à toa que a popularização do termo selfie ocorre paralelamente à proliferação dos telefones celulares com câmera e das redes sociais: no ano 2000 começou a ser vendido no Japão o primeiro celular com câmera; em 2002 aparece a primeira selfie em um fórum de discussão online (o avô das redes sociais); em 2003 é criada a rede social Myspace; em 2004 são criados o Orkut, o Facebook e o Flickr, que já nesse ano inclui a palavra selfie entre as etiquetas possíveis das fotos a serem compartilhadas; em 2006 metade dos celulares em uso tinha uma câmera embutida e em 2007 entra em circulação o $1^{\circ}$ Iphone; em 2010 já existia mais de um bilhão de celulares com câmera no mundo e começa a funcionar o Instagram.

Está criado assim o aparato tecnológico necessário para a expressão das subjetividades narcísicas do nosso tempo: em 2012 a palavra selfie passa a ser usada também nos meios de comunicação tradicionais; em 
2013 é eleita a palavra do ano pela Oxford Dictionaries; em 2014 o ator Bradley Cooper realiza uma selfie transmitida ao vivo durante a apresentação do Oscar, com a participação de uma penca de celebridades hollywoodianas que incluía atores como Meryl Streep, Jennifer Lawrence, Brad Pitt e Kevin Spacey: a foto foi postada no twitter da apresentadora Ellen DeGeneres e se tornou a foto mais retuitada da história, tendo sido replicada 2,7 milhões de vezes somente durante a cerimônia; em setembro do mesmo ano o canal de TV a cabo Warner Channel iniciou a exibição da série Selfie, sobre uma garota com milhares de seguidores nas redes sociais e dificuldades de relacionamento.

É somente neste contexto que a selfie do macaco, realizada em 2011, pode ter algum significado ou interesse. Como na situação das crianças de Aubervilliers, a fotografia disputada por David Slater não extrai seu interesse da beleza estética ou composição original; o que importa é a performance do próprio ato fotográfico. A força da foto não se encontra no produto imagético, mas no registro do acontecimento irreversível, de um lado, e na ressignificação inacabável da imagem como selfie, do outro. Também neste caso é na fotograficidade da foto, como eterna relação entre o irreversível e o inacabável, que encontramos o ponto de origem da sua força estética. E também neste caso somente os responsáveis pela criação do irreversível e do inacabável poderão ser justamente identificados como "autores" da obra.

Do lado do irreversível parece incontestável que o motivo principal para que a foto se tornasse famosa é a história do modo como ela foi realizada. Quando Slater não faz parte do processo tudo se torna muito mais fantástico, e a cena reproduzida se torna "mais verdadeira", por estar livre de influências racionais. O registro escapa do campo de intencionalidade do fotógrafo racional e se torna pura produção imagética, capaz de atribuir subjetividade e sensibilidade estética a um local de onde não se esperava que ela emergisse.

No entanto, é evidente que as coisas não se dão dessa forma. Slater é enfático em recordar que a produção do irreversível não ocorre de forma espontânea, mas envolve o duro trabalho material de seguir os animais pela floresta úmida, carregando $20 \mathrm{~kg}$ de caros equipamentos fotográficos. E é justamente por esse trabalho material que se considera o justo autor da fotografia, reivindicando os direitos dela correspondentes apesar de ter sido o macaco a apertar o botão. No entanto, ignora o fato de que a realização desse trabalho contou com a participação direta de pelo menos mais uma pessoa: o irrelevante guia anônimo responsável pelas tarefas pouco artísticas de conduzir o fotógrafo até o local onde estavam os animais, carregar parte do equipamento pesado, recuperar a câmera após ela ter sido roubada por duas vezes, fazer a primeira foto e até produzir a cena, gerando o insight do fotógrafo de deixar a câmera no tripé para que os macacos se fotografassem. Não bastasse, deve-se reconhecer também a participação anônima da coletividade responsável pelo desenvolvimento tecnológico que permitiu a criação dos instrumentos de registro da fotografia e a sua transcrição como imagem não somente dessa fotografia, mas de qualquer fotografia possível (os trabalhos de produção da cena, regulação da 
máquina, fixação e revelação do negativo). Desse modo, permanece inquestionavelmente coletivo o trabalho material de fixação do acontecimento irreversível em que o macaco tirou uma foto de si mesmo.

Mas também nesse caso, como no das crianças de Aubervilliers, o mais importante não é a produção, mas a legenda da foto: "a selfie do macaco". Se a estética da selfie é essencialmente objetificadora, pois coloca o autor da fotografia na posição de coisa submetida à avaliação do olhar alheio, no caso do macaco ocorre justamente o contrário: ao adotar o comportamento coisificante o animal se humaniza; ao se objetificar o macaco se torna sujeito (a ponto de se atribuir a ele a "autoria" da fotografia). É aí que se encontra o punctum da foto, capaz de lhe atribuir um suplemento de significado que "transpassa o espectador em seu âmago" (BARTHES, 1984:69) e a torna tão interessante. Sem a legenda a foto se torna completamente vazia de interesse.

E também nesse caso a legenda da foto não foi criada pelo fotógrafo; nem pelo macaco, nem pelo guia, nem pelo jornal que a divulgou, nem pela Wikimedia Foundation, nem pela PETA, mas por todo o contexto de reinterpretação e ressignificação coletiva que permite classificar a foto como uma espécie do gênero selfie e, a partir daí, atribuir-lhe o primeiro suplemento de significado, inerente a toda selfie, e o segundo, decorrente da subversão do gênero realizada por essa foto específica. O autor da legenda é o zeitgeist, é o desenvolvimento tecnológico, são as novas formas de sensibilidade estética, são os novos instrumentos materiais de produção cultural, são as novas formas de circulação cultural, e todos os membros da humanidade que contribuíram para a construção desses significados.

\section{O autor da legenda é a multidão}

Ubi enim sunt duo vel tres congregati in nomine meo, ibi sum in medio eorum. (Matthaeum, 18:20) 32. $^{2}$

\section{A Legenda da Legenda da Legenda}

Os casos discutidos não são interessantes por sua peculiaridade, mas por sua exemplaridade. Eles apenas expõem com mais clareza os dilemas obscuros da autoria na era da produção tecnológica e coletiva de bens culturais: como qualquer fotografia realizada no mundo contemporâneo, também estas são resultado de um trabalho material coletivo; como qualquer fotografia realizada no mundo contemporâneo, também estas criam afeto entre os partícipes do processo de produção; como qualquer fotografia realizada no mundo contemporâneo, também estas se dirigem a uma sociedade massificada; como qualquer fotografia realizada no mundo contemporâneo, também estas expressam a sensibilidade particular de seres humanos; como qualquer fotografia realizada no mundo contemporâneo, também estas são resultado de um complexo processo tecnológico; como

32 Porque, onde estiverem dois ou três reunidos em meu nome, aí estou eu no meio deles. (Mateus, 18:20). 
qualquer fotografia realizada no mundo contemporâneo, também estas dependem da legenda da coletividade para adquirir significado estético.

A tarefa que se apresenta hoje ao direito não é a de descobrir como proteger a propriedade ameaçada pelo desenvolvimento tecnológico; mas a de superar os limites do individualismo proprietário oitocentista, inventando formas jurídicas capazes de proteger e estimular não só a produção, mas principalmente a livre circulação dos produtos da criatividade e da sensibilidade da multidão - e, com ela, a livre geração de afetos intersubjetivos. Para esses objetivos o direito dos nossos tataravós é hoje apenas um obstáculo a ser superado.

Dicendo autem novum veteravit prius quod autem antiquatur et senescit prope interitum est (Hebreus, $8: 13)^{33}$.

\section{THE MONKEY SELFIE - AUTHORSHIP AND PHOTOGRAPHY IN CONTEMPORARY WORLD}

\section{Resumo}

The article focuses on the dispute over the photography entitled Monkey Selfie. Although the picture was taken by the monkey Naruto, professional photographer David Slater claims the authorship of the photo, which was uploaded to the Wikimedia Commons database and made available to a free use, starting a legal battle for its authorship. Leaving aside the dogmatic issues involved in the dispute, as the decision on the authorship, this article aims to analyze the case from a philosophical- critical perspective: taking into consideration the aesthetic debate about the nature of photographic production and the meaning of art in the age of mechanical reproduction, the Money Selfie is reinserted in the context of cultural industry and the rise of selfie as a photographic genre. Following Deleuze and Guattari's methodological recommendation, the text is organized in plateaus, in order to establish assemblages able to produce a cartography of the disputes around copyright nowadays. Thereby, this case is compared to other similar situations in order to expand the field of investigation, which leads to the conclusion that the case is not peculiar, but sinthomatic of the contemporary crisis of authorship.

Keywords: copyright; photography; aesthetics in photography; authorship; cultural industry.

\section{REFERÊNCIAS BIBLIOGRÁFICAS}

ANDRADE, Fábio (2010). O Homem das Novidades (The Cameraman) de Edward Sedgwick (EUA, 1928), in: Revista Cinética. Disponível no endereço eletrônico <http://www.revistacinetica.com.br/cameraman.htm> em março de 2010.

BARTHES, Roland (1984). A Câmara Clara: nota sobre a fotografia (trad.: Julio Castañon Guimarães). Rio de Janeiro: Nova Fronteira.

${ }^{33}$ Dizendo nova aliança, envelheceu a primeira. Ora, o que foi tornado velho, e se envelhece, perto está de acabar. (Hebreus, 8:13). 
BENJAMIN, Walter (1994a). Pequena história da fotografia, in: Magia e técnica, arte e política: ensaios sobre literatura e história da cultura - Obras Escolhidas, v. 1 (trad.: Sérgio Paulo Rouanet). São Paulo: Brasiliense, p. 91 107.

(1994b). A obra de arte na era de sua reprodutibilidade técnica, in: Magia e técnica, arte e política: ensaios sobre literatura e história da cultura - Obras Escolhidas, v. 1 (trad.: Sérgio Paulo Rouanet). São Paulo: Brasiliense, p. 165-196.

BOURDIEU, Pierre (2003). Un Arte Medio: ensayo sobre los usos sociales de la fotografia (trad.: Tununa Mercado, rev.: Sara Sánchez). Barcelona: Editorial Gustavo Gili.

DELEUZE, Gilles (2000). Mil Platôs: capitalismo e esquizofrenia, vol. 1. (trad. Ana Lúcia de Oliveira et alii). Rio de Janeiro: Editora 34.

EDELMAN, Bernard (1976). O Direito Captado pela Fotografia (elementos para uma teoria marxista do direito) (trad. Soveral Martins e Pires de Carvalho). Coimbra: Centelha.

FOUCAULT, Michel (2005). A Arqueologia do Saber (trad. Luiz Felipe Baeta Neves). 7a ed. Rio de Janeiro: Forense Universitária.

KANG, Jay Caspian (2014). Wikipedia defends the monkey selfie, in: The New Yorker, disponível no sítio eletrônico <http://www.newyorker.com/news/daily-comment/monkey-see-monkey-click> em 8 de agosto de 2014.

KRAUSS, Rosalind (2010). O Fotográfico. Barcelona: Gustavo Gilli.

SLATER, David J. (2014a). Sulawesi Macaques. Disponível no sítio eletrônico: <http://www.djsphotography.co.uk/original_story.html> em 10 de outubro de 2014.

(2014b). Monkey Selfie - photographer takes on Goliath. Disponível no sítio eletrônico: <http://www.djsphotography.co.uk > em 10 de outubro de 2014.

SONTAG, Susan (2006). Sobre la Fotografía (trad.: Carlos Gardini, rev.: Aurelio Major). México, D.F.: Santillana Ediciones Generales.

SOULAGES, François (2010). Estética da Fotografia: perda e permanência (trad.: Iraci D. Poleti e Regina Salgado Campos). São Paulo: Editora Senac São Paulo.

STAUT JÚNIOR, Sérgio Said (2006). Direitos Autorais: entre as relações sociais e as relações jurídicas. Curitiba: Moinho do Verbo.

TELEGRAPH (2011). Monkey steals camera to snap himself. Disponível no sítio eletrônico: $<$ http://www.telegraph.co.uk/news/newstopics/howaboutthat/8615859/Monkey-steals-camera-to-snaphimself.html> em 04 de julho de 2011.

Trabalho enviado em 29 de julho de 2015.

Aceito em 08 de agosto de 2015. 